\title{
Prevalence of skin diseases in children attending government vs private school in a rural set up in the sub-Himalayan region
}

\author{
Samriti Sood ${ }^{1}$, *Mudita Gupta ${ }^{1}$, Reena Kumari Sharma ${ }^{1}$, Saru Thakur ${ }^{2}$
}

Sri Lanka Journal of Child Health, 2020; 49(1): 54-58

\begin{abstract}
Background: The accessibility of health services is determined by the health status of its paediatric population. Skin problems are very common in children.
\end{abstract}

Objectives: To determine the prevalence and pattern of skin diseases in children in a rural set up in the sub-Himalayan region and to compare these between government and private schools.

Method: A cross-sectional study was done and all the students between 10-18 years, after taking informed consent from parents, were examined from head to toe. Those from government schools were included in group A and private schools in group B.

Results: Mean age and sex distribution in the two groups were similar. Crowding index and Kuppuswamy scale difference in the two groups were statistically insignificant. Dermatological manifestations were seen in $84.6 \%$ students of group A and $75.5 \%$ students in group B. Infective dermatological diseases were seen in $36.2 \%$ in group A vs $30.8 \%$ in group B. In both groups viral infection with human papilloma virus was the commonest. We did not have any case of bacterial skin infection. Infestations like scabies were seen only in private school students. Acne vulgaris was the most common non-infective disorder in both groups $(28.6 \%$ vs $20 \%)$ followed by callosities.

Conclusions: Skin diseases are very common in the paediatric population. Infective diseases were seen more in government school children but infestations were more in private school children.

${ }^{1}$ Indira Gandhi Medical College, India, ${ }^{2}$ Shri Lal Bahadur Shastri Government Medical College Hospital, India

*Correspondence: muditadrgupta@yahoo.com

(iD) https://orcid.org/0000-0001-8564-7011

(Received on 04 June 2019: Accepted after revision on 19 July 2019)

The authors declare that there are no conflicts of interest

Personal funding was used for the project.

Open Access Article published under the

Commons Attribution CC-BY (c) (i) License
DOI: http://dx.doi.org/10.4038/sljch.v49i1.8899

(Keywords: Dermatological diseases, private and government schools, infective dermatosis, noninfective dermatosis)

\section{Introduction}

India has $27.3 \%$ of the total population in the age group 0-14 years ${ }^{1}$. Prevalence of skin diseases among children in India ranges from $8.7 \%$ to $35 \%$ in school based surveys ${ }^{2}$. We conducted this study in a rural area in sub-Himalayan region with the primary aim of finding the prevalence of skin diseases among school-going children. Our secondary aim was to identify pattern of paediatric dermatosis and compare the prevalence of dermatological diseases in government and private schools.

\section{Objectives}

To determine the prevalence and pattern of skin diseases in children in a rural set up in the subHimalayan region and to compare these between government and private schools.

\section{Method}

The present study was undertaken by the department of dermatology of a tertiary care hospital after obtaining approval of the institutional ethical committee. We conducted a cross sectional study in 1000 school-going children and adolescents in the age group 10 to 18 years in a rural set up of a district in the sub-Himalayan region. Two schools run by government and one private school were included in the study. Informed consent to examine students and publish data was taken from the Principal of school as well as the legal guardians of the students.

There were 364 students from the 2 government schools and 636 students from the private school. We included all students between 10-18 years whose parents consented for the study. Those children were excluded whose parents had refused examination of their child and publication of data. Minor cutaneous diseases such as freckles, acquired melanocytic naevi and xerosis were not labelled as cutaneous disease. An easy to answer questionnaire was framed which included a number of variables including age, sex, address, housing conditions, including number of rooms and total number of family members, father' qualification, 
occupation and monthly family income. Socioeconomic status was calculated for each student using a modified Kuppuswamy scale and housing conditions were estimated by using crowding index. Crowding index (C.I) was calculated by using the formula:

C.I $=$ total number of family members, excluding newborns and infants, divided by the total number of rooms, excluding washroom and kitchen

CI was divided into three groups $<1,1-2$ and $>2$. According to Kuppuswamy index there were 5 groups (upper, upper-middle, lower-middle, upperlower and lower-lower). The students were examined from head to toe for various diseases of skin, hair and nails. Diagnosis was made clinically. No laboratory investigations or further workup was done.

Statistical analysis: Data was entered into the Microsoft Excel spreadsheets and analysed using Epi info7.7.2 software version. $p<0.05$ was considered to be significant.

\section{Results}

A total of 1000 students were included in the study, 364 belonging to the 2 government schools (group A) and 636 belonging to the private school (group B). Students in group A were in the age group of 11-17 years (mean age of 13.7 years) and in group $\mathrm{B}$ were in the age group of $10-18$ years (mean age 13.6 years). $\mathrm{p}$ value was calculated to be 0.806 . In group A, there were 136 females $(37.4 \%)$ and 228 males $(62.6 \%)$ and in group B, there were 256 females $(40.3 \%)$ and 380 males $(59.7 \%)$. In overall study, there were $63.6 \%$ males and $36.4 \%$ females. The mean C.I for group A was 2.12+-0.78 and for group B it was $2.15+-0.74$. The $\mathrm{p}$ value was 0.715 . $\mathrm{CI}$ of two groups is as shown in table 1

Table 1

Crowding index for both groups

\begin{tabular}{|c|c|c|}
\hline $\begin{array}{c}\text { Crowding } \\
\text { index }\end{array}$ & $\begin{array}{c}\text { Group A } \\
\text { percentage }\end{array}$ & $\begin{array}{c}\text { Group B } \\
\text { percentage }\end{array}$ \\
\hline$<1$ & 25.3 & 20.8 \\
\hline $1-2$ & 37.4 & 42.8 \\
\hline$>2$ & 37.4 & 36.5 \\
\hline
\end{tabular}

In group $\mathrm{A}$, majority of the students belonged to upper-lower $(36.6 \%)$ and lower $(33.0 \%)$ grade whereas only $2.2 \%$ and $4.4 \%$ belonged to upper and upper-middle grade respectively. Surprisingly $26.4 \%$ and $35.2 \%$ students in group B belonged to grade 4 and 5 and $8.8 \%$ and $11.9 \%$ belonged to grades 1 and 2 respectively. Modified Kuppuswamy scale for the two groups is shown in table 2. The difference in mean score of the two groups was 0.32 and was not significant.
Table 2

Modified Kuppuswamy scale for both groups

\begin{tabular}{|l|c|c|}
\hline $\begin{array}{c}\text { Kuppuswamy } \\
\text { grade }\end{array}$ & $\begin{array}{c}\text { Group A } \\
\text { n (\%) }\end{array}$ & $\begin{array}{c}\text { Group B } \\
\text { n (\%) }\end{array}$ \\
\hline Upper (1) & $08(02.2)$ & $56(08.8)$ \\
\hline Upper-middle (2) & $16(04.4)$ & $76(11.9)$ \\
\hline Lower-middle (3) & $88(24.2)$ & $112(17.6)$ \\
\hline Upper-lower (4) & $132(36.3)$ & $168(26.4)$ \\
\hline Lower-lower (5) & $120(33.0)$ & $224(35.2)$ \\
\hline
\end{tabular}

Dermatological manifestations were seen in $78.8 \%$ of total students. Of group A students $84.6 \%$ had cutaneous involvement compared to $75.5 \%$ of group B students $(p<0.05)$. In group A $17.6 \%$ students had infectious disorder, $48.4 \%$ had noninfectious disorder and $18.7 \%$ had both type of diseases. In group B, $13.8 \%$ had infectious disorder, $44.7 \%$ had non-infectious disorder and $17 \%$ had both. Infectious diseases were seen in 132 (36.2\%) students in group A and 192 (30.8\%) students in group B.

Among infectious dermatoses, viral infections were the most common being seen in $116(14.3 \%)$ group A students compared to $140(22.1 \%)$ group B students. It was followed by fungal infections in 48 $(13.2 \%)$ students in group A and $32(5 \%)$ students in group B. Scabies was found only in 40 students in group B whereas pediculosis capitis was found in both groups (Table 3 )

Table 3

Distribution of infectious dermatosis in both groups

\begin{tabular}{|l|c|c|}
\hline Infectious disorder & $\begin{array}{c}\text { Group A } \\
\text { n (\%) }\end{array}$ & $\begin{array}{c}\text { Group B } \\
\text { n (\%) }\end{array}$ \\
\hline Onychomycosis & $04(01.1)$ & $16(2.5)$ \\
\hline Tinea pedis & $24(06.6)$ & $16(2.5)$ \\
\hline Tinea versicolor & $16(04.4)$ & 0 \\
\hline Tinea faciei & $04(01.1)$ & 0 \\
\hline Warts & $48(13.2)$ & $108(17.0)$ \\
\hline $\begin{array}{l}\text { Molluscum } \\
\text { contagiosum }\end{array}$ & $4(01.1)$ & $24(03.8)$ \\
\hline Herpes simplex & 0 & $08(01.3)$ \\
\hline Scabies & 0 & $40(06.3)$ \\
\hline Pediculosis capitis & $08(02.2)$ & $20(03.1)$ \\
\hline
\end{tabular}

Among non-infectious dermatosis, acne vulgaris was the most common among both groups A and B (28.6\% vs $20 \%$ ) followed by callosities with a prevalence of $26.4 \%$ and $18.4 \%$ in groups A and B respectively. Among eczematous disorders, pityriasis alba was the most common in both groups. Pigmentary disorders were seen in $3.3 \%$ in group $\mathrm{A}$ and $6.8 \%$ in group B. Perniosis was observed in $6.6 \%$ and $7.5 \%$ students of group $\mathrm{A}$ and $\mathrm{B}$ respectively (Table 4 ) 
Table 4

Distribution of non-infectious dermatosis in both groups

\begin{tabular}{|l|c|c|}
\hline $\begin{array}{c}\text { Non-infectious } \\
\text { dermatosis }\end{array}$ & $\begin{array}{c}\text { Group A } \\
\text { n (\%) }\end{array}$ & $\begin{array}{c}\text { Group B } \\
\text { n (\%) }\end{array}$ \\
\hline Seborrheic dermatitis & $52(14.3)$ & $20(03.1)$ \\
\hline Hand dermatitis & $04(01.1)$ & 0 \\
\hline Nummular eczema & $04(01.1)$ & $08(01.3)$ \\
\hline Lip lick dermatitis & $08(02.2)$ & $04(0.6)$ \\
\hline Pityriasis alba & $16(04.4)$ & $128(20.1)$ \\
\hline Atopic dermatitis & $16(04.4)$ & $32(05.0)$ \\
\hline Keratosis pilaris & $44(12.1)$ & $100(15.7)$ \\
\hline Pigmentary disorders & $12(03.3)$ & $44(06.8)$ \\
\hline Acne vulgaris & $104(28.6)$ & $124(20.0)$ \\
\hline Hyperhidrosis & $56(15.4)$ & $80(12.6)$ \\
\hline Papular urticaria & $08(02.2)$ & $20(03.1)$ \\
\hline Perniosis & $24(06.6)$ & $48(07.5)$ \\
\hline Callosities & $96(26.4)$ & $120(18.4)$ \\
\hline
\end{tabular}

Among disorders of appendages, leukonychia was most commonly observed (Table 5)

Table 5

Distribution of nail and hair disorders in both groups

\begin{tabular}{|l|c|c|}
\hline $\begin{array}{l}\text { Nail and hair } \\
\text { disorders }\end{array}$ & $\begin{array}{c}\text { Group A } \\
\text { n (\%) }\end{array}$ & $\begin{array}{c}\text { Group B } \\
\text { n (\%) }\end{array}$ \\
\hline Leukonychia & $68(18.7)$ & $32(05.0)$ \\
\hline Hang nails & $08(02.2)$ & $20(03.1)$ \\
\hline Pincer nails & $12(03.3)$ & $08(01.3)$ \\
\hline Alopecia areata & $04(01.1)$ & $16(02.5)$ \\
\hline Hirsutism & $08(02.2)$ & $12(01.9)$ \\
\hline
\end{tabular}

\section{Discussion}

The type of cutaneous disorders prevalent in a community depends upon various factors like nutrition, climatic factors, housing conditions, general health awareness, education and socioeconomic status and most importantly accessibility and availability of health care facilities. In developing countries, especially in a rural background, infective dermatoses are expected to be more prevalent than non-infectious dermatoses. Thus, school health surveys are essential to estimate the true burden of any disease among children of a community. We had therefore, undertaken this study with the primary aim of finding the prevalence of skin diseases among the rural paediatric population. Our secondary aim was to compare the prevalence of these skin diseases in government schools and private schools and see the pattern of dermatological involvement.

The prevalence of skin diseases in children and adolescents in the age group 10 to 18 years was found to be $78.8 \%$ which was $84.6 \%$ for the government school and $75.5 \%$ for private schools. The prevalence in our study is in accordance with a few studies with prevalence of $68-77 \% \%^{3-5}$. However, some studies report very low prevalences of $38.8 \%$ and $14.3 \%$ which are much less when compared to our study ${ }^{6,7}$. The greater prevalence in our study is probably because we examined the students from head to toe rather than exposed sites only.

In our study, infectious dermatoses were present in $36.2 \%$ in group A and $30.8 \%$ in group B which are less when compared to studies by Jose et al (50.7\%), Negi et al. (50.7\%) and Valia et al. $(43 \%)^{3,8,9}$. In our study, infectious dermatoses were less probably because of better availability of health facilities and better insight into school students' personal hygiene. We did not have any patient with scabies in our government schools but there were such cases in the private school probably because of increased crowding in the private school.

Among infectious diseases, viral infections were most commonly seen in students of both government $(14.3 \%)$ and private $(22.1 \%)$ schools. Among viral infections, warts were most commonly seen followed by molluscum contagiosum and herpes simplex. Viral warts was also the most common infectious disease in the study by Yassen and Hassan ${ }^{4}$. This is in contrast to the other studies by Jose et al, Chouela et al. and Figueroa et al where pediculosis capitis was the most common infectious disease ${ }^{3,10,11}$. In our study, pediculosis capitis was seen in only $2.2 \%$ and $3.1 \%$ of government schools and private schools respectively. Scabies was seen in $6.3 \%$ students of the private school. No cases were seen in government schools. Scabies and pediculosis, being symptomatic, lead to treatment being sought early, whereas warts and molluscum being asymptomatic are usually ignored. Among fungal infections, tinea pedis was the most common infection seen in $6.6 \%$ and $2.5 \%$ students of government and private schools respectively). It was followed by onychomycosis, tinea corporis and tinea facei. Tinea pedis was the commonest fungal infection probably because of lack of awareness of foot hygiene (changing socks, drying and cleaning of toe webs and shoes). In contrast to other studies, where pyodermas or other bacterial infections were common, in our study we had no such case probably because of pain/fever parents tends to seek early medical care which is easily available at our set up.

In our study the non-infectious dermatoses were seen in a greater number of students accounting for the prevalence of $67.1 \%$ for government and $61.7 \%$ for private schools, which is much more compared to the studies conducted by Jose et al $(37.1 \%)$ and Negi et al $(31.6 \%)^{3,8}$. We detected many patients with callosities and perniosis, which are likely to be more due to cold weather and hilly terrain. We did 
not have any child with nutritional dermatosis in contrast to other studies ${ }^{8}$.

Among the non-infectious dermatoses, acne vulgaris was found to be the most common with a prevalence of $28.6 \%$ and $20 \%$ in government and private schools respectively. The high prevalence may be attributable to the age distribution with more number of adolescents in our study and due to over the counter availability of skin lightening creams and other cosmetics. A prevalence of $19.2 \%$ of acne vulgaris has been observed by Yaseen and Hassan $^{4}$. The second common non-infectious dermatoses in our study were callosities in $26.4 \%$ and $18.4 \%$ students in government and private schools respectively. Callosities were not reported in previous similar studies conducted on schoolgoing children, but in our study, callosities, especially plantar callosities, were found in a significant number of students. This might be due to the topography of our state, where walking for long distances, and that too, walking up and down hills, leads to friction and development of callosities. Hyperhidrosis, seen in a significant number of students, may be due to lack of awareness of foot hygiene.

Cold injury such as perniosis was seen in $6.6 \%$ students of the government schools and 7.5\% students of the private school. Children are more predisposed to develop perniosis on exposure to cold damp climatic conditions. Studies from warmer areas have reported cases of miliaria. Among eczematous disorders, pityriasis alba was commonly observed in the private school and its prevalence was significantly higher $(20.1 \%)$ in students of the private school than in those of government schools (4.4\%). Keratosis pilaris, seborrheic dermatitis, hand eczema, lip lick dermatitis and atopic dermatitis were other dermatoses noted. Yaseen and Hassan also found pityriasis alba to be the most common eczematous disorder $(15.8 \%)$, followed by irritant, allergic and hand eczema $(4.6 \%)^{5}$.

Papular urticaria was observed in $2.2 \%$ and $3.1 \%$ students of government and private schools respectively. It is comparable to a study conducted by Jose et al $(2.63 \%)$ and Ghosh et al who also observed a frequency of $4 \%$ in their study ${ }^{3,12}$. Higher insect bite reactions have been reported in other studies. The lower incidence in our study may be because of cooler, cleaner, and less dense environment than in previous studies ${ }^{13}$. Among pigmentary disorders, vitiligo was seen in $4(1.1 \%)$ students in government schools and $8(1.3 \%)$ students in private school. Dogra et al reported pigmentary disorders in $2.6 \%$ of children ${ }^{6}$. Among other cutaneous autoimmune diseases we observed discoid lupus erythematosus (DLE) in 2 cases only.
All the cases of vitiligo and DLE were on treatment.

Among nail disorders, leuconychia was the most common with a prevalence of $18.7 \%$ and $5 \%$ in government and private schools respectively. Incidence of hair and nail disorders were reported to be $4.2 \%$ by Nupane et al. ${ }^{14}$. Among hair disorders, alopecia areata was seen in $1.1 \%$ and $2.5 \%$ whereas hirsutism was seen in students $2.2 \%$ and $1.9 \%$ of government and private school respectively.

\section{Conclusions}

Cutaneous involvement is very common among paediatric age group in the three schools studied. Chronic infective conditions like warts and onychomycosis were common infections seen. In non-infective disorders rather than deficiency disorders we found acne vulgaris to be the commonest.

\section{References}

1. National Family Health Survey (NFHS) IV (2015-2016)". International Institute for Population Sciences, Ministry of Health and Family Welfare, Government of India. 2016.

2. Janaki M, Jaiganesh D, Rajendran AK, Anitha R. Prevalence of skin diseases among Government primary school children in Pulianthope Zone, Chennai. India International Journal of Recent Trends in Science and Technology 2013; 9: 182-5.

3. Jose G, Vellaisamy SG, Govindarajan N, Gopalan K. Prevalence of common dermatoses in school children of rural areas of Salem; a region of South India. Indian Journal of Paediatric Dermatology 2017; 18: 202-8.

https://doi.org/10.4103/2319-7250.206090

4. Rao GS, Kumar P, Kuruvilla M. Prevalence of various dermatoses in school children. Indian Journal of Dermatology Venereology and Leprology 1999; 65: 126-7.

5. Yaseen U, Hassan I. Prevalence of various skin disorders in school going children of Kashmir valley of North India: A crosssectional study. Indian Journal of Paediatric Dermatology 2013; 14:67-72. https://doi.org/10.4103/2319-7250.122166 
6. Dogra S, Kumar B. Epidemiology of skin diseases in school children: A study from Northern India. Pediatric Dermatology 2003; 20: 470-3.

https://doi.org/10.1111/j.15251470.2003.2 0602.x

PMid: 14651562

7. Sharma NK, Garg BK, Goel M. Pattern of skin diseases in urban school children. Indian Journal of Dermatology Venereology and Leprology 1986; 52: 330-1.

8. Negi KS, Kandpal SD, Parsad D. Pattern of skin diseases in children in Garhwal region of Uttar Pradesh. Indian Pediatrics 2001; 38:77-80.

9. Valia RA, Pandey SS, Kaur P, Singh G. Prevalence of skin diseases in Varanasi school children. Indian Journal of Dermatology Venereology and Leprology 1991; 57: 141-3.

10. Chouela E, Abeldaño A, Cirigliano M, Ducard M, Neglia V, La Forgia M, et al. Head louse infestations: Epidemiologic survey and treatment evaluation in Argentinian schoolchildren. International Journal of Dermatology 1997; 36: 819-25. https://doi.org/10.1046/j.13654362.1997.0 0177.x

PMid: 9427073
11. Figueroa JI, Hawranek T, Abraha A, Haya RJ. Prevalence of skin diseases in school children in rural and urban communities in the Illubabor province, South-Western Ethiopia: A preliminary survey. Journal of the European Academy of Dermatology and Venereology 1997; 9: 142-8. https://doi.org/10.1016/S09269959(97)001 05-0

12. Ghosh SK, Saha DK, Roy AK. A clinicoaetiological study of dermatoses in paediatric age group. I International Journal of Dermatology 1995; 40: 29-31.

13. Bangaru H, Nanjundaswamy BL. Pattern of pediatric dermatoses in a tertiary care centre in Karnataka. Indian Journal of of Clinical and Experimental Dermatology 2016; 2:5-7.

14. Neupane S, Pandey P. Spectrum of dermatoses among paediatric patients in a teaching hospital of western Nepal. Nepal Journal of Dermatology, Venereology and Leprology 2012; 10: 20-26.

https://doi.org/10.3126/njdvl.v10i1.6419 